\title{
ANALISIS KESALAHAN DALAM MENGGUNAKAN POSSESIVEPRONOMEN BAHASA JERMAN
}

\author{
Sri Meragnes Sitanggang ${ }^{1}$, Syarifah Fatimah ${ }^{2}$ dan Syukur Saud ${ }^{3}$ \\ Jurusan Bahasa Asing, Fakultas Bahasa dan Sastra \\ Universitas Negeri Makassar \\ Email: sri.meragnes@yahoo.co.id ${ }^{1}$
}

\begin{abstract}
ABSTRAK
Penelitian ini bertujuan untuk mendapatkan data dan informasi tentang kesalahan siswa kelas XI SMAN 8 Makassar dalam menggunakan Possesivpronomen. Jenis penelitan ini adalah deskriptif kualitatif. Pengambilan data dilakukan dengan tes menulis karangan dalam bahasa Jerman. Metode analisis yang digunakan adalah metode analisis kesalahan yang dikemukakan oleh Ellis. Hasil analisis data menunjukkan bahwa rata-rata kesalahan Possesivpronomen dalam karangan sederhana siswa adalah 50\% yang berada pada kategori tinggi. Kesalahan penggunaan Possesivpronomen yang dimaksud dalam hal ini terdiri dari dua aspek diantaranya kesalahan penggunaan Possesivpronomen dalam bentuk Nominativ yaitu 71,07\% dan dalam bentuk Akkusativ yaitu 28,92\%. Faktor penyebab munculnya kesalahan tersebut adalah faktor performansi dan kompetensi.
\end{abstract}

Kata Kunci: Kesalahan Berbahasa, Possesivepronomen, Bahasa Jerman.

\begin{abstract}
This study aims to obtain data and information about student error in using Possesivpronomen. This type of research is descriptive qualitative. Data collection is done by writing essay writing in German. The analytical method used is the error analysis method proposed by Ellis. The result of data analysis shows that the average of Possesivpronomen error in the student's simple essay is 50\% which is in the high category. Errors of Possesivpronomen in question consists of two aspects such as misuse of Possesivpronomen in the form of Nominativ is $71,07 \%$ and in the form of Akkusativ that is $28,92 \%$. Factors causing the error is a factor of performance and competence.
\end{abstract}

Keywords: Error Analysis, Possesivepronomen, German Language.

\section{PENDAHULUAN}

Bahasa sebagai alat interaksi manusia memiliki peranan yang penting dalam kehidupan sehingga harus dipelajari secara lebih mendalam baik di lingkungan pendidikan formal dan nonformal. Bahasa yang dipelajari di Indonesia diantaranya adalah bahasa daerah sebagai bahasa ibu, bahasa Indonesia sebagai bahasa nasional dan bahasa asing sebagai bahasa internasional. Sementara itu, alasan mengapa bahasa asing harus dipelajari di sekolah 
adalah untuk mengembangkan kemampuan berkomunikasi menggunakan bahasa lain, agar dapat berkomunikasi dengan orang yang berasal dari luar negeri dan mempersiapkan diri untuk bersaing di era globalisasi ini.

Kemampuan berbahasa asing bukanlah sesuatu yang dapat diajarkan melalui uraian atau penjelasan semata-mata. Siswa tidak dapat memperoleh keterampilan berbahasa hanya dengan duduk mendengarkan penjelasan dari guru dan mencatat, namun, dibutuhkan usaha dan keterampilan lain. Mengingat pentingnya bahasa sebagai alat komunikasi, maka dalam proses pembelajaran bahasa juga harus diarahkan pada tercapainya keterampilan berkomunikasi baik secara lisan atau tertulis dalam hal pemahaman dan penggunaannya (Romadloni dkk, 2017; Yusri dkk, 2018).

Bahasa Jerman sebagai mata pelajaran telah diajarkan di sekolah-sekolah di Indonesia pada jenjang pendidikan menengah seperti SMA. Hal ini merupakan wujud kesadaran pentingnya penguasaan bahasa asing, khususnya bahasa Jerman yang digunakan sebagai bahasa internasional. Sebagaimana dengan pembelajaran bahasa asing lainnya, pembelajaran bahasa Jerman juga terdiri atas empat kompetensi berbahasa. Keempat kompetensi tersebut ditunjang oleh dua aspek penting lainnya yaitu kosakata (Wortschatz) dan tata bahasa (Grammatik), keduanya merupakan dasar dalam penguasaan keterampilan berbahasa. Setiap aspek ini memiliki hubungan yang erat antara satu keterampilan dengan keterampilan lainnya.

Penguasaan kosakata (Wortschatz) merupakan suatu kewajiban bagi para pembelajar bahasa, akan tetapi bukan hanya memperluas penguasaan kosakata (Wortschatz) saja, namun penguasaan tata bahasa (Grammatik) yang baik dan benar juga sangat diperlukan. Tanpa penguasaan tata bahasa yang baik dan benar, para pembelajar bahasa yang sedang mempelajari bahasa tersebut akan kesulitan dalam berbicara dan juga menulis.

Dalam mempelajari tata bahasa (Grammatik) khususnya tata bahasa Jerman dibutuhkan usaha dan kerja keras serta rasa ingin tahu yang tinggi supaya dapat mengusai tata bahasa tersebut, karena setiap tata bahasa (Grammatik) memiliki aturan atau kaidah masing-masing.

Dalam pembelajaran bahasa Jerman ada beberapa aspek tata bahasa (Grammatik) yang merupakan dasar dalam membuat sebuah kalimat diantaranya konjugasi kata kerja (Konjugation), kata ganti orang (Personalpronomen), kata ganti kepunyaan (Possesivpronomen), dan lain-lain. Kata ganti kepunyaan (Possesivpronomen) merupakan salah satu aspek yang paling sulit untuk dipahami oleh siswa. Hal ini didukung dengan adanya sebuah observasi yang dilakukan terhadap siswa kelas XI IPA dan kelas XI IPS di SMAN 8 Makassar pada tanggal 29 September 2016 bahwa siswa masih mengalami kesulitan dalam menggunakan kata ganti kepunyaan (Possesivpronomen). Hal ini dapat diketahui dari hasil tugas yang dikerjakan oleh siswa yang menunjukkan hanya $20 \%$ dari 30 siswa yang dapat menyelesaikan tugas dengan benar.

Terjadinya kesalahan berbahasa di kalangan siswa yang sedang belajar bahasa terutama belajar bahasa sasaran, merupakan fenomena yang mendorong para pengajar bahasa untuk mempelajari kesalahan berbahasa. Dari studi kesalahan berbahasa itu dapat diketahui bahwa proses terjadinya kesalahan berbahasa berhubungan erat 
dengan proses belajar bahasa sasaran sehingga untuk memahami proses terjadinya kesalahan berbahasa terutama di kalangan siswa yang sedang belajar bahasa, diperlukan pemahaman tentang tata bahasa (Grammatik).

Penelitian ini diperkuat oleh hasil penelitian yang telah dilakukan sebelumnya oleh Anggreani (2012:3) menunjukkan bahwa kemampuan menggunakan possesive pronomen siswa kelas XI SMA Negeri 1 Makassar berada pada kategori rendah yaitu 43,41 \%. Selain itu, Hasil penelitian oleh Ismail (2012:43) menunjukkan bahwa kemampuan menggunakan possesive pronomen dalam kalimat bahasa Jerman siswa kelas XI SMA Negeri 1 Tinambung Kabupaten Polman adalah belum memadai yakni hanya 49,03 \%. Hal yang sama juga diteliti oleh Nasrianti (2014:38) yang menunjukkan bahwa kemampuan menggunakan Possesivpronomen dalam bahasa Jerman siswa kelas XII IPS SMA Negeri 1 Alla Kabupaten Enrekang berada pada kategori cukup yakni ; 69,53\%.

\section{HAKIKAT ANALISIS KESALAHAN}

Pembelajaran bahasa pada dasarnya adalah proses mempelajari Bahasa (Jufri, 2007; Jufri, 2017). Dalam mempelajari bahasa tentu tidak luput dari kesalahan. Analisis kesalahan adalah pengkajian segala aspek kesalahan. Hastuti (2003:73) mengemukakan bahwa analisis kesalahan adalah proses didasarkan pada analisis orang yang sedang belajar dengan suatu objek yang jelas. Adapun objek yang dimaksud dalam penelitian ini merupakan siswa yang mempelajari bahasa Jerman.

Crystal dalam Ayuningsih (2012:5) mengemukakan bahwa analisis kesalahan adalah suatu teknik untuk mengidentifikasi, mengklasifikasi, dan menginterpretasikan secara sistematik kesalahan-kesalahan yang dilakukan oleh siswa yang sedang mempelajari bahasa asing atau bahasa kedua dengan menggunakan teori atau prosedur linguistik.

Azis (2007:74) mengemukakan bahwa analisis kesalahan adalah segala bentuk kesalahan dalam bahasa atau tidak sesuai dengan kaidah penggunaan bahasa yang baik dan benar yang harus diperbaiki atau dikoreksi agar penggunaannya lebih baik dan benar. Veijonen (2008:15) menjelaskan bahwa kesalahan adalah sebuah penyimpangan sistem bahasa seperti tata bahasa, penggunaan kata dan aturan berbahasa.

Dari beberapa pendapat di atas, dapat ditarik kesimpulan bahwa analisis kesalahan adalah pengkajian segala aspek kesalahan untuk mengetahui kesalahan-kesalahan yang dilakukan oleh siswa yang sedang mempelajari bahasa asing dan hasil analisis kesalahan tersebut dapat digunakan sebagai dasar dalam memperbaiki komponen proses belajar bahasa asing berikutnya.

Tujuan analisis kesalahan juga dikemukakan oleh Tarigan (2011:61-62) yaitu: (1) menentukan urutan penyajian halhal yang diajarkan dalam kelas dan buku teks, misalnya urutan mudah-sulit; (2) menentukan urutan jenjang relatif penekanan, dan latihan berbagai hal bahan yang diajarkan. (3) merencanakan latihan dan pengajaran remedial; (4) memilih hal-hal bagi pengujian kemahiran siswa. Tarigan (2011:69) mengatakan bahwa tujuan analisis kesalahan bersifat aplikatif, yakni memperbaiki dan mengurangi kesalahan berbahasa para siswa. Tujuan tersebut ternyata mengabaikan hal yang penting, yakni penyusunan atau pengembangan teori penjelasan mengenai performansi siswa. Padahal, tujuan analisis 
kesalahan tidak hanya bersifat aplikatif tetapi juga bersifat teoritis. Dari beberapa beberapa pendapat di atas, dapat disimpulkan bahwa tujuan analisis kesalahan adalah untuk memberikan informasi kepada guru atau pengajar bahasa mengenai kekurangan dalam proses pembelajaran yang sudah ada, pengajaran dan latihan yang telah dilakukan, merencanakan program pengajaran remedial serta dapat mengetahui aspek-aspek kebahasaan yang belum dikuasai oleh siswa.

Langkah-langkah dalam menganalisis kesalahan merupakan salah satu bagian yang penting dari analisis kesalahan itu sendiri. Hal ini bertujuan agar proses analisis tersusun secara sistematis dan terarah. Analisis kesalahan mempunyai tujuan yang sangat baik. Azis (2007:55) mengungkapkan bahwa tujuan analisis kesalahan berbahasa yaitu (1) menentukan urutan penyajian butir-butir yang diajarkan dalam kelas atau buku teks, misalnya urutan mudah-sukar; (2) menentukan urutan jenjang relatif penekanan, penjelasan dan latihan berbagai butir yang diajarkan; (3) merencanakan latihan dan pengajaran; (4) memilih butir pengujian kemahiran siswa.

Analisis kesalahan berbahasa adalah suatu prosedur kerja, sehingga dalam menganalisis kesalahan tersebut membutuhkan langkah-langkah yang sistematis agar hasil yang diperoleh dari analisis kesalahan tersebut memberikan manfaat dalam proses pembelajaran bahasa. Ellis dalam Tarigan (2011:60) menjelaskan bahwa langkah-langkah untuk menganalisis kesalahan meliputi pengumpulan sampel, pengidentifikasian kesalahan, penjelasan kesalahan, pengklasifikasian kesalahan dan pengevaluasian kesalahan.

Tarigan (2011:63) menjelaskan tentang langkah-langkah kerja baru analisis kesalahan melalui penyeleksian, pengurutan, dan penggabungan. Hasil modifikasi tersebut diambil inti sarinya sebagai berikut: mengumpulkan data, mengidentifikasi dan mengklasifikasi kesalahan, memperingkat kesalahan, menjelaskan kesalahan, memprakirakan atau memprediksi daerah atau hal kebahasaan yang rawan, dan mengoreksi kesalahan. Dari beberapa pendapat di atas, dapat disimpulkan bahwa langkah-langkah dalam menganalisis kesalahan yaitu pengumpulan sampel, pengidentifikasian kesalahan, penjelasan kesalahan, pengklasifikasian kesalahan, dan pengevaluasian kesalahan.

\section{METODE PENELITIAN}

Penelitian ini merupakan penelitian deskriptif kualitatif. Penelitian deskriptif kualitatif adalah metode penelitian yang berlandaskan filsafat postpositivisme, digunakan untuk meneliti pola kondisi objek yang alamiah dimana peneliti adalah instrumen kunci, teknik pengambilan data dilakukan secara tringulasi (gabungan), analisis data bersifat induktif (kualitatif) dan hasil penelitian kualitatif lebih menekankan makna dari pada generalisasi (Sugiyono, 2014:9). Hal yang dideskripsikan dalam penelitian ini yaitu kesalahan penggunaan Possesivpronomen dalam karangan sederhana siswa kelas XI SMA Negeri 8 Makassar.

Variabel yang digunakan dalam penelitian ini adalah variabel tunggal yakni kesalahan penggunaan Possesivpronomen dalam Nominativ dan Akkusativ. Kesalahan yang dimaksud dalam penelitian ini yaitu ketepatan penggunaan Possesivpronomen sesuai dengan Genus (Maskulin, Feminin, Neutral) dan jenis Plural. Populasi dalam penelitian ini adalah seluruh siswa kelas XI IPA SMA Negeri 8 Makassar yang berjumlah 
204 orang terbagi menjadi 6 kelas. Sampel dalam penelitian ini yaitu lembar kerja siswa kelas XI IPA 1 yang berjumlah 34 orang. Peneliti menggunakan teknik secara acak (random sampling) dalam pengambilan sampel data.

Data dalam penelitian ini adalah karangan sederhana yang dibuat oleh siswa yang menggunakan Possesivpronomen. Instrumen yang digunakan adalah tes mengarang. Siswa diberikan tugas untuk membuat sebuah karangan sederhana. Peneliti telah memberikan beberapa kata kunci sebagai alat bantu bagi siswa untuk membentuk beberapa kalimat sehingga menjadi sebuah karangan sederhana Data dalam penelitian ini dianalisis dengan menggunakan metode analisis kesalahan yang dikemukakan oleh Ellis dalam Tarigan (2011:60).

\section{HASIL DAN PEMBAHASAN}

Data yang diuraikan berikut ini yaitu data kesalahan siswa dalam ketepatan menggunakan kata ganti kepunyaan (Possesivpronomen) yang terdapat dalam karangan sederhana yakni dengan memperhatikan ketepatan penggunaan Possesivpronomen sesuai dengan Genus dalam bentuk Maskulin, Feminin, Neutral dan Plural serta kesalahan-kesalahan tersebut dilihat dari kesalahan pemberian akhiran yang benar dan sesuai dengan Artikel (kata sandang) yang mengikuti kata benda jenis Maskulin, Feminin, dan Neutral serta Plural dalam bentuk Nominativ maupun Akkusativ.

Hasil dalam penelitian ini adalah sebuah karangan sederhana dengan judul "Die Familie”. Sebelum hasil penelitian berupa kesalahan-kesalahan penggunaan Possesivpronomen dipaparkan sesuai dengan jenis kesalahannya, terlebih dahulu peneliti akan memaparkannya secara keseluruhan dengan mengklasifikasikan dan menghitung berdasarkan klasifikasi jenis kesalahan Possesivpronomen, yaitu kesalahan Possesivpronomen im Nominativ dan Akkusativ.

Berdasarkan hasil analisis, dapat diketahui bahwa jumlah kesalahan yang dilakukan oleh siswa sebanyak 121 kesalahan. Kesalahan-kesalahan tersebut terdiri atas kesalahan-kesalahan penggunaan Possesivpronomen dalam bentuk Nominativ dan kesalahan-kesalahan penggunaan Possesivpronomen dalam bentuk Akkusativ. Dari kedua klasifikasi kesalahan tersebut, kesalahan-kesalahan penggunaan Possesivpronomen dalam bentuk Nominativ mempunyai frekuensi tertinggi yaitu 86 kesalahan dengan persentasi $71,07 \%$ dari keseluruhan kesalahan-kesalahan penggunaan Possesivpronomen yang dibuat siswa. Selanjutnya terdapat kesalahankesalahan penggunaan Possesivpronomen dalam bentuk Akkusativ sebanyak 35 kesalahan atau 28,92\% dari keseluruhan kesalahan penggunaan Possesivpronomen dalam bentuk Akkusativ yang dibuat siswa.

Hasil penelitian menunjukkan bahwa frekuensi kesalahan penggunaan Possesivpronomen dalam bentuk Nominativ yang terdapat pada karangan sederhana bahasa Jerman siswa berjumlah 86 kesalahan. Kesalahan penggunaan Possesivpronomen dalam bentuk Feminin merupakan kesalahan yang paling banyak muncul dalam karangan sederhana siswa yakni dengan jumlah 31 $(25,61 \%)$ kesalahan. Kesalahan penggunaan Possesivpronomen dalam bentuk Maskulin merupakan kesalahan paling banyak kedua dengan jumlah 29 (24,79\%). Kesalahan penggunaan Possesivpronomen dalam bentuk Plural dengan jumlah $21 \quad(17,35 \%)$ 
merupakan kesalahan ketiga paling banyak dalam karangan sederhana siswa dan kesalahan penggunaan Possesivpronomen dalam bentuk Neutral sebanyak 5 (3,30\%) merupakan kesalahan paling sedikit yang terdapat dalam karangan sederhana siswa.

Hasil penelitian menunjukkan bahwa frekuensi kesalahan penggunaan Possesivpronomen dalam bentuk Akkusativ yang terdapat pada karangan sederhana bahasa Jerman siswa berjumlah 35 (28,92\%) kesalahan. Kesalahan penggunaan Possesivpronomen dalam bentuk Feminin dan Plural sebanyak $1 \quad(0,82 \%)$ merupakan kesalahan paling sedikit yang terdapat dalam karangan sederhana siswa. Kesalahan penggunaan Possesivpronomen dalam bentuk Maskulin sebanyak $3(2,47 \%)$ merupakan kesalahan kedua paling sedikit yang terdapat dalam karangan sederhana siswa. Sementara itu, kesalahan paling banyak yaitu berjumlah $30 \quad(24,79 \%)$ dikarenakan siswa tidak menggunakan Possesivpronomen dalam bentuk Akkusativ. Sedangkan pada petunjuk soal telah diperintahkan untuk menggunakan Possesivpronomen dalam bentuk Nominativ dan Akkusativ.

\section{KESIMPULAN}

Berdasarkan hasil analisis data, dapat disimpulkan bahwa rata-rata kesalahan penggunaan Possesivpronomen pada karangan bahasa Jerman siswa kelas XI IPA 1 SMA Negeri 8 Makassar adalah 50\%. Jumlah keseluruhan kesalahan yang dilakukan oleh siswa adalah 121 kesalahan yang berada pada kategori tinggi. Adapun kesalahan penggunaan Possesivpronomen dalam bentuk Nominativ berada pada kategori tinggi sekali yaitu 86 kesalahan atau 71,07\%. Sedangkan kesalahan dalam bentuk Akkusativ berada pada kategori cukup yaitu 35 kesalahan atau
$28,92 \%$ dari keseluruhan penggunaan Possesivpronomen.

Munculnya kesalahan penggunaan Possesivpronomen yang terdapat pada karangan siswa disebabkan oleh faktor performansi dan faktor kompetensi. Faktor performansi adalah faktor yang disebabkan karena performa siswa dalam mengarang. Performa yang dimaksud adalah kondisi emosional siswa dalam mengarang. Sedangkan faktor kompetensi adalah ketidaktahuan siswa tentang kaidah-kaidah atau aturan dalam bahasa Jerman terutama dalam kasus Nominativ dan Akkusativ.

\section{DAFTAR PUSTAKA}

Ayuningsih, Faridhotun Dwi. 2012. Analisis Kesalahan Berbahasa pada Penulisan Pengalaman Pribadi Siswa Kelas X A SMK Batik 2 Surakarta, Surakarta. Skripsi. Fakultas Keguruan dan Ilmu Pendidikan Universitas Muhammadiyah Jakarta. (Online) Diakses pada tanggal 19 Januari 2017 pada Pukul 14:02 WITA.

Azis, Abdul. 2009. Menulis Lanjut. Garut: YAF Garut Jawa Barat.

Hastuti, Sri. 2003. Sekitar Analisis Kesalahan Berbahasa Indonesia. Yogyakarta: Gema Widya.

Jufri, J. 2007. Metode Penelitian Bahasa. Sastra dan Budaya.

Jufri, J., 2017. Strategi Pembelajaran Bahasa. Nasrianti, 2014. Kemampuan menggunakan Possesivpronomen dalam Bahasa Jerman Siswa Kelas XII IPS SMA N 1Alla Kabupaten Enrekang. Makassar. Skripsi. FBS UNM.

Romadloni, A., \& Mantasiah, R. Intercultural approach in foreign language learning to improve students' motivation. Senior Editors, 61. 
Sugiyono, 2014. Metode Penelitian Tarigan, Henry Guntur. 2008. Menulis. Kuantitatif Kualitatif Dan $R \& D$. Bandung: Percetakan Angkasa.

Bandung: Penerbit Alfabeta. $\quad$ Yusri, Y., Mantasiah, R., \& Jufri, J. 2018. The

Tarigan, Henry Guntur dan Djago Tarigan. Use Of Two Stay Two Stray Model in 2011. Pengajaran Analisis Kesalahan English Teaching to Increase Student's Berbahasa. Bandung: Penerbit Learning Outcome. Journal of Angkasa Bandung. $\quad$ Advanced English Studies, 1(1), 39-43. 